\title{
PENGEMBANGAN APLIKASI E-LEARNING EDU IT : PEMBUATAN APLIKASI UJIAN ESSAY ONLINE SERTA UPLOAD DOWNLOAD MATERI KULIAH
}

\author{
Maria Bellaniar Ismiati*1, Latius Hermawan ${ }^{2}$ \\ ${ }^{1,2}$ Universitas Katolik Musi Charitas Palembang \\ Email: ${ }^{1}$ bella@ukmc.ac.id, ${ }^{2}$ tiuz.hermawan@ukmc.ac.id \\ *Penulis Korespondensi
}

(Naskah masuk: 01 September 2021, diterima untuk diterbitkan: 18 Oktober 2021)

\begin{abstract}
Abstrak
Dunia pendidikan sekarang sudah banyak yang menggunakan kecanggihan teknologi dan berbasis internet, seperti proses belajar mengajar secara elektronik atau dikenal dengan e-learning. Salah satu fitur e-learning dalam proses belajar mengajar adalah dapat menampilkan materi, soal latihan, percakapan melalui text/video maupun video, kuis, dan ujian secara elektronik. Contoh di dunia Pendidikan yang menggunakan e-learning adalah Universitas Katolik Musi Charitas yang merupakan salah satu Perguruan Tinggi Swasta di Palembang. Selama ini di UKMC, ujian masih dilakukan secara konvensional yaitu menggunakan kertas yang nantinya akan memperbanyak tumpukan kertas yang sudah ada sebelumnya. Selain itu, distribusi materi kuliah masih sering dilakukan melalui flashdisk/e-mail. Tujuan penelitian ini adalah untuk membuat aplikasi ujian essay online serta upload download materi kuliah di satu aplikasi (pengembangan dari aplikasi portal tugas). Pembuatan aplikasi ini dapat membantu proses konvensional untuk berkembang dengan menggunakan teknologi dan secara real time. Proses pengerjaan penelitian ini dimulai dari Requirements Planning, User Design, Construction, dan Cutover hingga yang terakhir adalah pembuatan laporan akhir penelitian. Penelitian ini akan menampilkan suatu menu dropdown yaitu soal Essay dengan soal-soal yang perlu dijawab dengan lengkap dan detail. Selanjutnya akan tampil nilai untuk masing-masing mahasiswa. Selain itu pada aplikasi ini juga akan ditambahkan suatu menu untuk upload dan download materi kuliah sehingga nantinya akan menjadi suatu e-learning yang lengkap. Hasilnya adalah interaksi antara mahasiswa dan dosen tidak hanya dapat dilakukan secara konvensional, tetapi dapat pula dilakukan secara daring/online dan dapat mengurangi tumpukan kertas.
\end{abstract}

Kata kunci: e-learning, essay online, upload, download, internet.

\section{E-LEARNING APPLICATION DEVELOPMENT (EDU IT) : CREATION OF ONLINE ESSAY EXAM APPLICATION AND UPLOAD DOWNLOAD OF LECTURE MATERIALS}

\begin{abstract}
The world of education is now many who use technological sophistication and internet based, such as the process of teaching electronic learning/which is known as e-learning. One of the e-learning features in the teaching and learning process is that it can display materials, exercises, conversations through text/video or videos, quizzes, and exams electronically. During this time in UKMC, exams are still done in conventional way, namely using paper that will reproduce the papers that are not used anymore. In addition, the distribution of lecture materials is still often done through flash or e-mail. The purpose of this research is to make an online essay exam application as well as upload downloadable lecture material in one application which is a development of portal task application. This research will temporarily be tested to information and informatics systems students. The creation of this application can help the conventional process to evolve using technology and in real time. The process of this research is started from requirements Planning, User Design, Construction, and Cutover until the last is the generation of final research report. This research will show a drop down menu which is Essay about essay with questions in the form of essays that need to be answered with complete and detail. In addition to this application will also be added a menu to upload and download lecture materials so it will later become a complete e-learning. The result is that the interactions between students and lecturers are not conventionally and can reduce paperless.
\end{abstract}

Keywords: e-learning, essay online, uploads, downloads, Internet. 


\section{PENDAHULUAN}

Teknologi berkembang dengan sangat pesat bukan hanya di bidang bisnis ataupun kesehatan tetapi juga di bidang pendidikan. Dalam bidang pendidikan, dimulai awal tahun 2020 semua proses belajar-mengajar dilakukan secara daring/online. Hal tersebut dikarenakan virus COVID-19 yang menyerang seluruh dunia dan dikatakan sebagai pandemi. Dikarenakan virus tersebut sangat cepat menular, maka semua aktivitas pembelajaran tidak diperkenankan melalui tatap muka sehingga para guru maupun dosen harus menggunakan suatu aplikasi/tools dalam mendukung proses belajarmengajar tersebut.

Salah satu Universitas yang menggunakan konsep belajar daring adalah Universitas Katolik Musi Charitas (UKMC) yang berlokasi di Palembang. UKMC sudah sejak bulan Maret 2020 melaksanakan perkuliahan secara daring dengan menggunakan tools pendukung untuk belajar secara daring. Salah satu aplikasi yang mendukung proses belajar-mengajar tersebut adalah e-learning. $E$ learning merupakan salah satu jenis belajar mengajar yang dapat menyampaikan bahan ajar ke siswa menggunakan Internet, intranet bahkan media jaringan komputer yang lain (Hartley, 2001). Metode e-learning diharapkan dapat membantu pengajaran maupun pelajaran secara lebih baik dan efektif. Pengajaran sangat terbantu karena dengan menggunakan sistem pembelajaran elektronik, distribusi materi akan lebih efisien dan proses evaluasi serta penilaian bisa berlangsung secara real time.

Berdasarkan pengalaman peneliti, materi kuliah biasanya disampaikan secara konvensional, yaitu setelah dosen selesai menjelaskan materi akan ditransfer melalui flashdisk atau dikirim melalui email. Hal tersebut akan menyebabkan seringnya human error seperti ada materi yang lupa di-copy, mahasiswa lupa mentransfer ke mahasiswa lainnya, data terhapus dari flashdisk, bahkan data di flashdisk dapat hilang karena virus. Apabila melalui e-mail, materi tersebut bisa saja tidak terkirim atau masuk ke spam yang akan membuat bingung mahasiswa dan dosen yang bersangkutan. Hal tersebut tentu saja akan berpengaruh terhadap waktu dan manajemen materi kuliah dari sisi mahasiswa. Sedangkan untuk ujian, masih secara konvensional yaitu berupa kertas. Seringnya setelah ujian, meja dosen akan penuh dengan kertas-kertas ujian tersebut sebelum akhirnya dikembalikan lagi ke mahasiswa yang bersangkutan. Selain itu, dosen masih harus memeriksa satu per satu jawaban mahasiswa dengan beragam jenis tulisan tangan yang berbeda-beda. Hal tersebut tentu akan memakan banyak waktu dalam proses penilaian dan koreksinya.

Berdasarkan latar belakang beserta permasalahan yang telah dijelaskan di atas, dibuatlah penelitian dengan judul Pengembangan Aplikasi ELearning Edu IT : Pembuatan Aplikasi Ujian Essay
Online serta Upload Download Materi Kuliah. Tujuan dibangunnya aplikasi ini adalah agar dosen dan mahasiswa dapat memanajemen materi kuiah dengan baik karena telah disimpan dalam 1 server secara online. Sedangkan untuk ujian essay online, agar sistem pengerjaan dan penilaian dapat lebih efektif dan efisien dan dapa paperless. Dalam penelitian ini akan menggunakan Rapid Application Development untuk mendukung proses pembangunan perangkat lunaknya dan di dalamnya juga ada proses untuk perhitungan algoritmanya. Algoritma yang digunakan adalah TF-IDF dan Cosine Similarity. Algoritma TF-IDF sangat penting digunakan karena algoritma ini untuk melakukan proses perhitungan bobot setiap kata sesuai dengan rumus TF-IDF sedangkan algoritma selanjutnya yang juga penting adalah Cosine Similarity karena dengan algoritma ini dapat mengetahui tingkat kemiripan dari dokumen yang diuji.

\section{METODE PENELITIAN}

\subsection{Tahapan Penelitian}

\section{a. Tahap I}

Pada tahap ini, user (mahasiswa) dan analis (peneliti) bertemu untuk mengidentifikasi tujuan dibuatnya aplikasi serta informasi-informasi lainnya yang dibutuhkan dalam membuat aplikasi ini. Hasil yang diharapkan dari tahapan ini adalah daftar identifikasi, baik kebutuhan fungsional maupun kebutuhan nonfungsional. Pada tahap ini peneliti menggali lebih dalam mengenai aplikasi portal tugas yang telah dibuat di penelitian sebelumnya tentang apa saja yang dapat ditambahkan agar sistem ini dapat menjadi suatu e-learning yang utuh. Di dalam sistem ini sudah tersedia menu dan proses untuk upload dan download tugas yang diberikan oleh dosen, dan kuis online dengan sifat ujian Pilihan ganda. Selanjutnya untuk mengembangkan sistem ini menjadi suatu elearning, peneliti menambahkan menu untuk soal ujian yang mempunyai sifat ujian Essay online agar melengkapi portal tugas yang telah dibuat. Selain itu, peneliti juga menambahkan menu untuk upload dan download materi kuliah. Tahap ini masuk ke dalam tahap requirements planning dalam RAD.

\section{b. Tahap 2}

Pada tahap ini peneliti mulai mendesain dan melakukan perbaikan desain apabila masi ada yang belum sesuai antara keinginan user dan analis. Keaktifan user dalam memberikan komentar / pendapat mengenai desain antarmuka sangat dibutuhkan agar dapat segera mencapai tujuan yaitu diselesaikannya aplikasi Edu-IT tersebut. Berdasarkan identifikasi kebutuhan yang telah dibuat, selanjutnya akan dilakukan analisis perangkat lunak yang akan dibangun. Hasil analisis berupa pemodelan perangkat lunak yang siap dirancang. Dalam penelitian ini, hasil analisisnya 
adalah dibuatnya suatu menu soal ujian yang digabungkan menjadi satu di aplikasi portal tugas. Isi menu dari soal ujian ini adalah data mahasiswa, data soal ujian, data waktu ujian, hasil tes, dan menu untu admin. Semua menu tersebut dibuat untuk mendukung aplikasi ujian essay online tersebut agar dapat membantu dosen dan mahasiswa untuk paperless. Tahap ini masuk ke dalam tahap user design dalam RAD.

\section{c. Tahap 3}

Pada langkah constructions ini tujuannya adalah membuat sistem sesuai dengan hasil desain yang telah dibahas antara user dan analis di tahap 2 di atas. Berdasarkah hasil desain tersebut, pembangunan aplikasi ini dilakukan melalui pengkodean program atau proses coding. Model perangkat lunak yang telah dibuat pada tahap II, akan diterjemahkan dalam bentuk desain perangkat lunak yang siap dikodekan dengan bahasa pemrograman HTML, CSS, PHP MySQL, Javascript. Setelah semua interface menu dan alur logika aplikasi selesai dibuat, maka programmer akan mulai bekerja untuk masuk ke tahap coding programnya. Perangkat lunak ini berbasis website agar dapat diakses secara online dan real time. Tahap ini masuk ke dalam tahap constructions dalam RAD.

\section{Tahap 4}

Pada tahap ini, pengkodean perangkat lunak akan dilakukan. Pengkodean yang dimaksud adalah programmer membuat script-script coding yang diketikkan dalam suatu notepad (istilah layar putih dalam suatu bahasa pemrograman) yang setelah itu disimpan untuk selanjutnya dapat dilakukan proses execute atau running. Pengkodean menggunakan bahasa pemrograman PHP dengan menggunakan database MySQL. Programmer mulai bekerja di tahap ini dengan menggunakan panduan dari tahap 1-3 yang sudah dijelaskan di atas. Hasil dari kegiatan ini adalah sebuah perangkat lunak berbasis website. Tahap ini masuk ke dalam tahap constructions dalam RAD.

\section{Tahap 5}

Tahap terakhir yang dilakukan adalah tahap cutover. Tahap ini merupakan tahap akhir yaitu konversi data, pengujian aplikasi ujian essay online ke pengguna serta pelatihan pengguna dalam menggunakan aplikasi kuis online tersebut. Pada tahap ini, akan dilakukan pengujian aplikasi secara langsung ke pengguna terhadap website yang sudah dibuat. Pengujian ini adalah ketika mahasiswa mengerjakan aplikasi ujian essay online tersebut secara real time. Setelah selesai mengerjakan, dilakukan pengecekan apakah hasil yang keluar sudah sesuai, yaitu aplikasi dapat menampilkan nilai ujian mahasiswa berdasarkan tingkat kemiripan antara jawaban mahasiswa dan kunci jawaban yang telah dibuat oleh dosen sehingga dapat mempermudah dosen dalam penilaian. Tahap ini masuk ke dalam tahap cutover dalam RAD.

\subsection{Alat Penelitian}

Alat penelitian yang mendukung pembuatan aplikasi ujian essay online serta upload dan download materi kuliah adalah Laptop dan mouse. Semua alat penelitian ini berupa hardware yang saling mendukung satu sama lain.

\subsection{Alat Analisis}

Alat analisisnya adalah kuisioner dan statistika deskriptif. Kuisioner diberikan kepada pengguna aplikasi ujian essay online dan menu upload serta download materi kuliah. Sedangkan statistika deskriptif digunakan untuk menghitung persentase dari jawaban ya dan tidak yang diberikan oleh responden.

\subsection{Kebutuhan Data}

Data-datanya berupa pertanyaan ujian dan kunci jawaban yang dibuat oleh dosen serta jawaban yang diberikan oleh mahasiswa saat ujian dilakukan. Pertanyaan beserta kunci jawaban yang dibuat oleh dosen dapat dilihat pada Gambar 1 dan jawaban yang diberikan oleh mahasiswa dapat dilihat pada Gambar 2 di bawah ini.

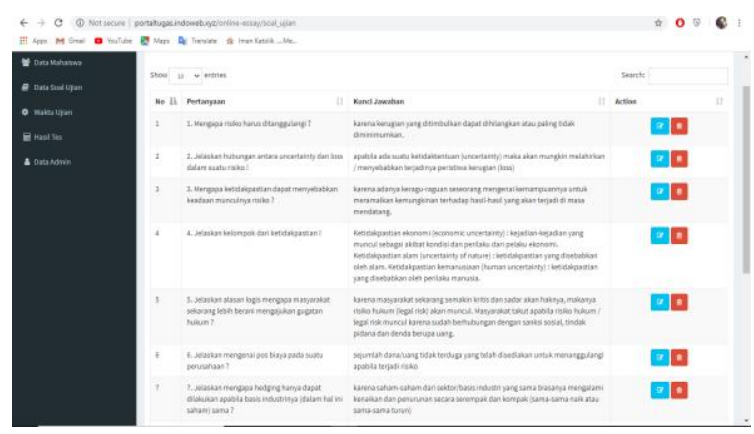

Gambar 1. Pertanyaan dan Kunci Jawaban dari Dosen

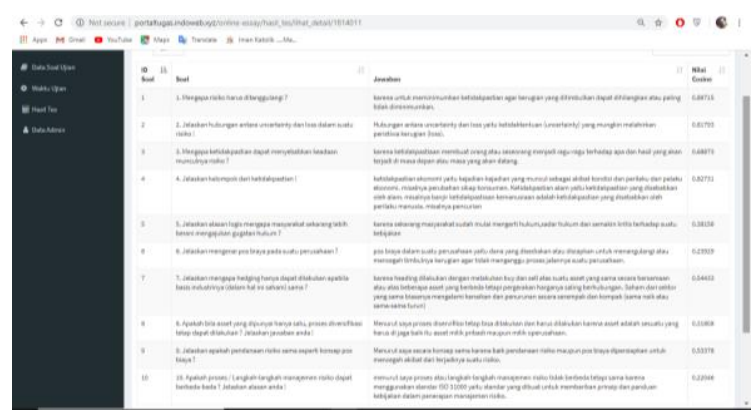

Gambar 2. Jawaban dari Mahasiswa beserta Nilai Cosine Mahasiswa

\subsection{Tools yang Digunakan}

Tools yang digunakan dalam mendukung penelitian ini adalah Microsoft Word, bahasa pemrograman 
(PHP dan Javascript), HTML, CSS, MySQL, sublime, xampp, dan Google form. Google form digunakan sebagai tools untuk mengisi kuisioner akhir dari responden.

\subsection{Pengujian}

Pengujian ini dilakukan dengan cara memberikan link google form agar mahasiswa yang sudah melaksanakan ujian essay online dapat memberikan feedback mengenai aplikasi ini. Selain ujian essay online, mahasiswa juga memberikan pendapatnya mengenai fitur upload dan download materi kuliah. Link untuk pengujian aplikasi ujian essay online adalah https://forms.gle/2ZMCwiDN8j6RK9dy8 sedangkan link untuk pengujian menu upload dan download materi-materi kuliah untuk mahasiswa adalah https://forms.gle/yxbHJRs6WD8DfPR27. Responden dapat langsung mengisi pertanyaanpertanyaan berkaitan dengan tanggapan mahasiswa saat menggunakan e-learning Edu IT tersebut.

\section{TINJAUAN PUSTAKA}

\subsection{Aplikasi}

Perangkat lunak aplikasi adalah bagian dari komputer yang menggunakan kemampuannya untuk mengerjakan tugas yang diberikan oleh pengguna, contohnya adalah Microsoft Office. Microsoft Office merupakan aplikasi pengolah kata yang dapat digunakan oleh pengguna untuk membuat suatu dokumen. Aplikasi tersebut biasanya mempunyai antarmuka yang sudah dikenal oleh pengguna agar pengguna tidak kesulitan dalam mempelajari dan menggunakannya. Dan seringnya aplikasi-aplikasi tersebut dapat saling berinteraksi satu sama lain dengan aplikasi lain untuk membantu pengguna menyelesaikan tugasnya (Safaat, 2012).

\subsection{E-Learning}

\section{E-Learning}

adalah jenis belajar-mengajar yang dapat menyampaikan bahan ajar ke siswa dengan menggunakan internet, intranet bahkan media jaringan komputer lain. E-learning merupakan pembelajaran tanpa adan batas ruang serta waktu. Sekarang, setiap orang mencari pembelajaran yang berorientasi pada kebutuhan individu masing-masing (dengan kesibukan yang berbeda-beda pula). Oleh karena itu, E-learning adalah solusi untuk para profesional karena dengan menggunakan ini, dapat belajar dimana saja, serta kapan saja hanya melalui elektronik di tangan pengguna (Hartley, 2001).

\subsection{Ujian}

Tes bisa berbentuk tertulis, lisan, dan praktik atau kinerja. Tes yang jawabannya berupa isian (isian singkat / uraian) biasa disebut dengan essay. Dalam proses penilaian, tes dilakukan secara berkelanjutan melalui banyak jenis ulangan dan ujian. Ujian merupakan kegiatan yang dilakukan untuk mengukur pencapaian kompetensi peserta didik sebagai hasil dari prestasi belajar / penyelesaian dari suatu satuan Pendidikan (Arikunto, 2008).

\subsection{Upload dan Download}

Upload / unggah menurut Kamus Besar Bahasa Indonesia (KBBI) adalah proses yang digunakan untuk mengirimkan file menggunakan internet. Sedangkan download /unduh adalah proses menyimpan / mengunduh file yang ada di suatu server / perangkat lain melalui internet. Bila user ingin menyimpan suatu file, maka user harus melakukan proses upload dan bila user membutuhkannya lagi, maka user harus melakukan proses download.

\subsection{Rapid Application Development (RAD)}

Rapid Application Development (RAD) atau rapid prototyping adalah model pembangunan perangkat lunak yang tergolong dalam teknik bertingkat. RAD mempunyai siklus pembangunan pendek, singkat, dan cepat. Rapid application development menggunakan metode iteratif dimulai dari requirements planning, user design, construction, dan cutover (Britton, 2001). Proses iterasi dari RAD ditampilkan pada Gambar 3 di bawah ini.

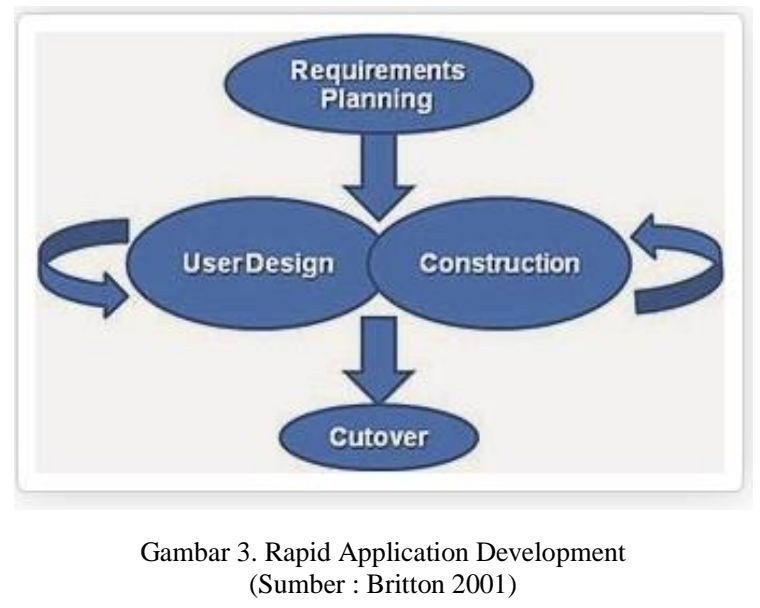

\subsection{Algoritma TF-IDF dan Cosine Similarity}

Term Frekuensi-Inverse Document Frekuensi (TF-IDF) adalah proses perhitungan bobot dari frekuensi kemunculan / jumlah kemunculan suatu token/kata di dalam dokumen (Rahmawati, 2011). Dengan kata lain, TF-IDF memang berguna untuk mencari nilai bobot dari dokumen. Algoritma TFIDF memeriksa berapa banyak kata yang muncul pada isi dokumen yang ada dari hasil pre processing text. Rumus perhitungan TF-IDF adalah :

$$
\begin{aligned}
& W_{i j}=t f x \text { idf } \\
& W_{i j}=t f_{i j} x\left(\left(\log \frac{N}{n}\right)+1\right)
\end{aligned}
$$


Dimana :

Wij : bobot kata/term/token ke-j dan dokumen ke-i. tfij : jumlah kemunculan kata/term/token ke-j dalam dokumen ke-i.

idf $: \log \mathrm{N} / \mathrm{n}+1$

$\mathrm{N}$ : jumlah semua dokumen yang ada.

$\mathrm{n}$ : jumlah dokumen yang mengandung token/kata/term ke-j.

Sedangkan untuk Consine Similarity, berguna dalam melakukan proses perhitungan kesamaan dari dokumen dengan menggunakan rumus :

$$
\text { Similarity Value }(S V)=\cos \theta \frac{\mathrm{AB}}{|\mathrm{A} \| \mathrm{B}|}
$$

Dimana :

A : vektor A

B : vektor B

$\|\mathrm{A}\|$ : panjang vektor $\mathrm{A}$

$\|\mathrm{B}\|$ : panjang vektor $\mathrm{B}$

\subsection{Penelitian Terdahulu}

Hignasari (2020) mempunyai penelitian yang bertujuan untuk mengembangkan media e-learning dengan menggunakan metode self-assessment untuk meningkatan hasil belajar matematika mahasiswa. Model yang digunakan adalah model ADDIE. Sample dari penelitian ini adalah mahasiswa Prodi Teknik Industri, Fakultas Teknik Universitas Mahendradatta yang berjumlah 39 mahasiswa. Datanya didapatkan dari hasil posttest (yang selanjutnya dianalisis dengan menggunakan uji Paired T-Test) yang diberikan kepada mahasiswa setelah melaksanakan pembelajaran e-learning dengan metode self- assessment. Selanjutnya digunakan one group pretest and posttest design untuk mengetahui efektivitas implementasi $e$ learning. Hasil uji Paired T-Test adalah terdapat perbedaan antara nilai hasil belajar sebelum dan sesudah dimplementasikan e-learning yang disertai dengan peningkatan nilai rata-rata hasil belajar matematika mahasiswa, yaitu dari nilai pre-test sebesar 75,92 meningkat menjadi 82,10.

Sari (2020) melakukan penelitian mengenai evaluasi dari e-learning di Universitas Negeri Padang (UNP). Penelitian ini menggunakan metode kuantitatif. Evaluasi e-learning di UNP menggunakan model kesuksesan sistem informasi, yaitu DeLone \& McClean. Penelitian ini ingin mendapatkan bagaimana gambaran e-learning UNP. Hasil analisis datanya adalah kualitas sistem mencapai kategori baik dilihat dari tingkat capaian responden (TCR), kualitas informasi dikategorikan baik, kualiatas layanan dikategorikan baik, penggunaan dikategorikan baik, kepuasan pengguna dikategorikan baik. Dan manfaat bersih dikategorikan baik. Jadi, kesimpulannya adalah $e$ learning UNP memiliki hasil pengukuran baik pada semua variabel pengukuran. Hal tersebut tentunya akan mempengaruhi penggunaan pada $e$-learning itu sendiri, terutama saat e-learning tersebut dikelola oleh tenaga pendidik dan saat digunakan oleh peserta didik.

Hoetamy (2020) membuat penelitian di SMK Veteran Kota Jambi yang merupakan salah satu lembaga pendidikan tingkat menengah kejuruan di J1. Yos Sudarso Km.2 Kel. Kasang Jaya Kec. Jambi Timur. Selama ini sistem pembelajaran yang dilakukan di SMK Veteran Kota Jambi masih berlangsung secara konvensional. Permasalahan yang ada selama proses pembelajaran konvensional tersebut adalah terbatasnya waktu belajar-mengajar yang membuat guru tidak bisa memberikan soal-soal latihan untuk siswa serta materi yang tidak bisa diberikan jika guru berhalangan hadir di kelas. Tujuan dari penelitian ini adalah untuk membuat Elearning yang nantinya akan digunakan sebagai sarana pendukung kegiatan belajar-mengajar. ELearning dibuat dengan menggunakan suatu bahasa pemrograman dan database MySQL serta menggunakan metode pengembangan sistem yaitu model waterfall. E-learning ini berbasis android yang dapat memudahkan guru dalam mendistribusikan soal-soal latihan kepada siswa, memeriksa hasil latihan yang dilakukan siswa, serta menjadi sarana pembelajaran jarak jauh karena aplikasi dapat diakses secara online atau daring.

Susanti (2020) mempunyai tujuan penelitian untuk merancang aplikasi pembelajaran e-learning bahasa Inggris berbasis multimedia. Konsep aplikasinya adalah berupa gabungan dari teks, gambar, animasi, dan video. Penelitian ini menggunakan subjek siswa SMA kelas X. Metode pengembangan sistem menggunakan System Development Live Cycle (SDLC) serta untuk pendukung implementasi aplikasi pembelajarannya, digunakan Moodle. Selain itu untuk menganalisis dan merancang sistemnya menggunakan metode Unified Modelling Language (UML). Peneliti berhasil membuat e-learning yang dapat dijadikan sebagai media pembelajaran Bahasa Inggris untuk tingkat pemula dengan tema learning by doing. Elearning ini dibuat untuk membantu meningkatkan proses belajar bahasa Inggris terutama dalam membaca, menghapal, dan mengucapkan kosakata E-Learning.

\section{HASIL DAN PEMBAHASAN}

\subsection{Proses Pencocokan Kata}

Setelah dosen melakukan input pertanyaan dan jawaban, sistem akan menyimpan data tersebut ke dalam database. Jika jumlah soal sudah ditentukan oleh dosen, maka dosen tersebut harus menekan tombol proses data. Proses ini dilakukan agar jawaban dari setiap pertanyaan yang telah dibuat dapat dilakukan proses text preprocessing (case folding - tokenizing - filtering - stemming). Proses selanjutnya adalah proses indexing, fungsinya untuk 
mendapatkan daftar kata penting atas pertanyaan yang dibuat oleh dosen.

Pada bagian mahasiswa, saat mahasiswa sudah selesai menjawab pertanyaan yang ditentukan oleh sistem maka mahasiswa harus menekan tombol kirim jawaban. Setelah melakukan proses tersebut, sistem akan langsung melakukan text preprocessing agar didapatkan daftar kata penting atas pertanyaan yang telah dijawab mahasiswa.

Proses selanjutnya adalah melakukan perbandingan indeks yang terdapat pada jawaban dosen dan mahasiswa. Pengecekan dilakukan dengan melakukan perhitungan jumlah kata penting terhadap seluruh kata yang ada dalam indeks jawaban dosen. Disinilah algoritma TF-IDF (Term Frequency - Inverse Dokumen Frequency) bekerja, yaitu melakukan proses perhitungan bobot setiap kata sesuai dengan rumus TF-IDF.

Selanjutnya setelah didapatkan setiap bobot kata pada jawaban mahasiswa terhadap jawaban dosen, akan dilanjutkan dengan mengukur tingkat kesamaan jawaban dengan menggunakan Cosine Similarity dari hasil teks yang telah diproses pada perhitungan TF-IDF. Tujuan dari proses ini yaitu untuk mengetahui tingkat kemiripan dari dokumen yang diuji. Proses Cosine similarity adalah untuk mengukur kedekatan dua vektor (dalam hal ini bobot setiap kata dalam 1 kalimat akan dibandingkan dengan bobot kata jawaban dosen dalam 1 kalimat). Cosine similarity merupakan hasil dot product kedua vektor tersebut yang dinormalisasikan dengan cara dibagi dengan Euclidean Distance antara kedua vektor tersebut. Hasil yang didapatkan adalah angka kedekatan jarak setiap kalimat yang ada.

Hasil dari bobot tersebut akan dikalikan 10 agar didapat skor dengan rentang 1-10. Setelah semua jawaban dibandingkan dan dilakukan perkalian 10 pada setiap hasil cosine similiarity, sistem akan menjumlahkan keseluruhan hasil cosine similiarity yang didapat pada setiap jawaban soal dan akhirnya dibagi dengan keseluruhan jumlah soal. Sehingga didapatlah nilai akhir mahasiswa (jika terdapat koma, akan dibulatkan ke atas).

\subsection{Antar Muka Aplikasi}

Antar muka aplikasi dalam penelitian ini dibagi dalam 2 bagian, yaitu antar muka dari sisi dosen dan antar muka dari sisi mahasiswa. Antar muka dari sisi dosen ditampilkan pada Gambar 4 hinggan Gambar 15 sedangkan untuk antar muka dari sisi mahasiswa ditampilkan pada Gambar 16 hingga Gambar 23. Peneliti membagi dua bagian agar semua tampilan layer dari kedua sisi antar muka dapat terlihat dan dapat lebih dimengerti oleh pembaca. a. Tampilan Login (Dosen)

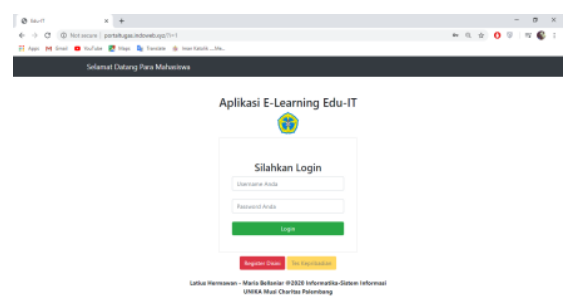

Gambar 4. Tampilan Login E-Learning Edu IT

b. Tampilan Awal E-Learning Edu IT

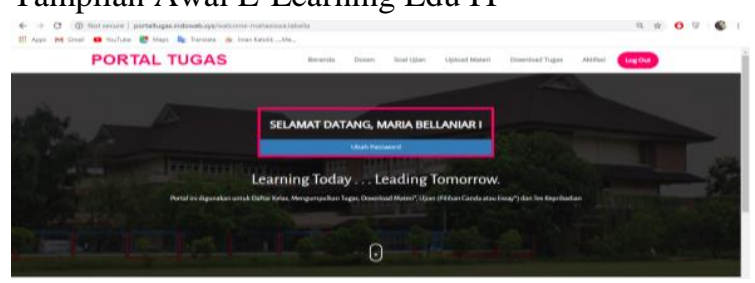

Gambar 5. Tampilan Awal E-Learning Edu IT

c. Tampilan Menu Soal Ujian

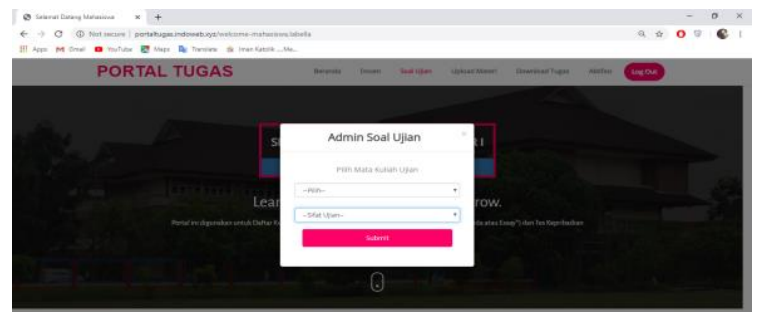

Gambar 6. Tampilan form untuk Pilih Mata Kuliah yang akan diberi Ujian

d. Tampilan Halaman Admin untuk Pengelolaan Soal Ujian

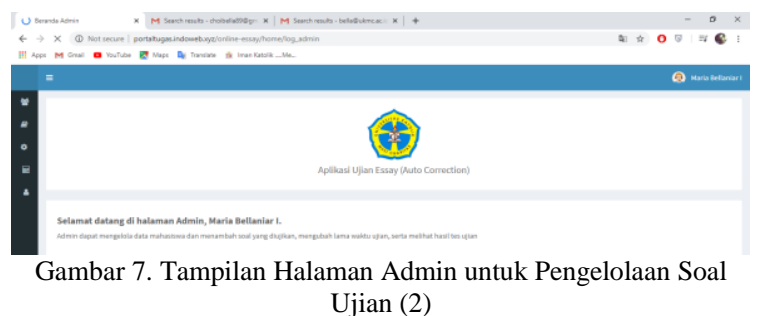

e. Tampilan Halaman Data Soal Ujian

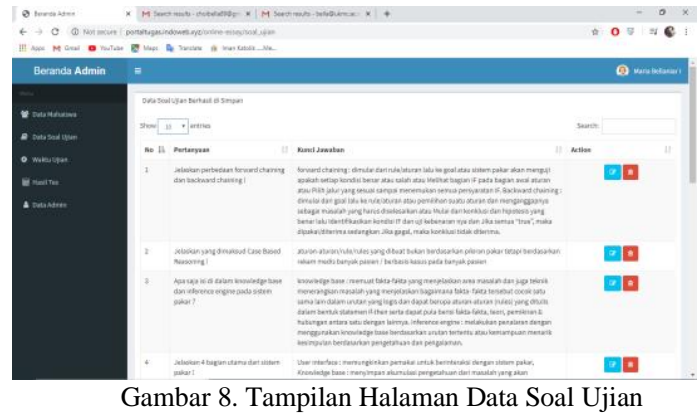


f. Tampilan Halaman Input Data Soal Ujian

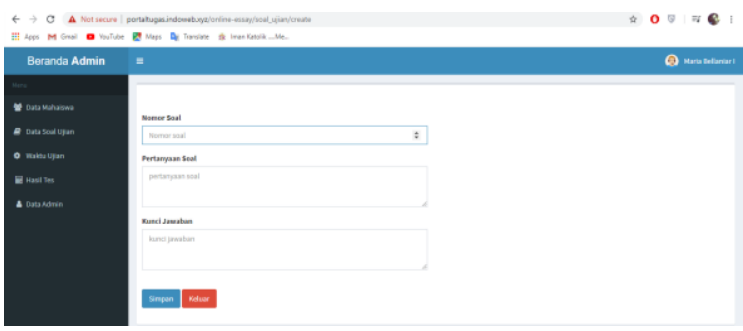

Gambar 9. Tampilan Halaman Input Data Soal Ujian

g. Tampilan Halaman Hasil Tes Mahasiswa

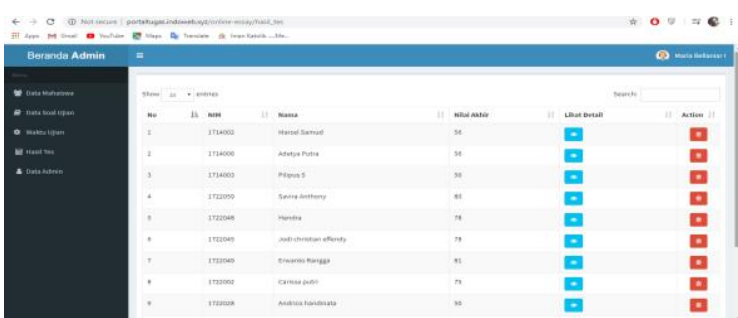

Gambar 10. Tampilan Halaman Hasil Tes Mahasiswa

h. Tampilan Halaman Jawaban Mahasiswa beserta Nilai Cosine

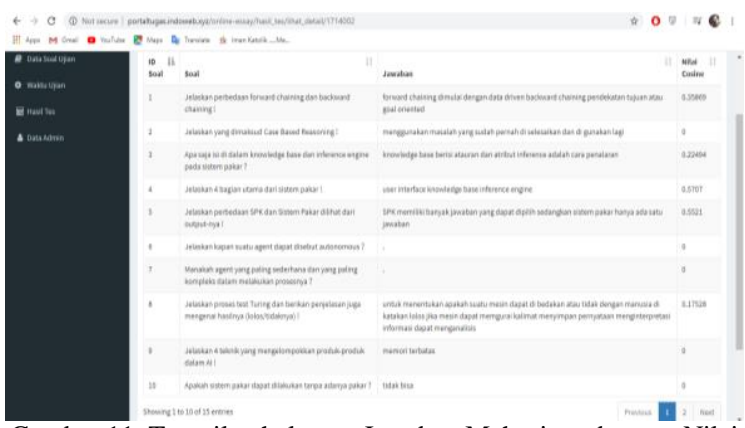

Gambar 11. Tampilan halaman Jawaban Mahasiswa beserta Nilai Cosine-nya

i. Tampilan Logout Menu Soal Ujian

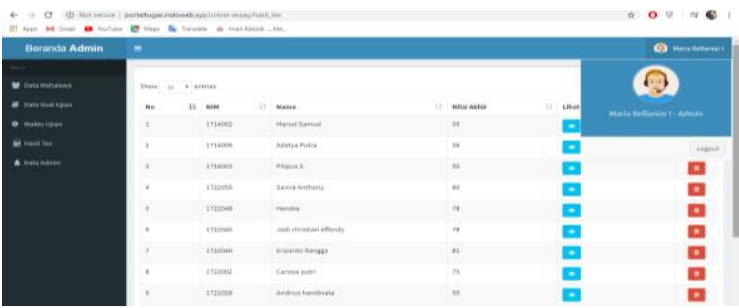

Gambar 12. Tampilan Logout Menu Soal Ujian

j. Tampilan Menu Upload Mata Kuliah

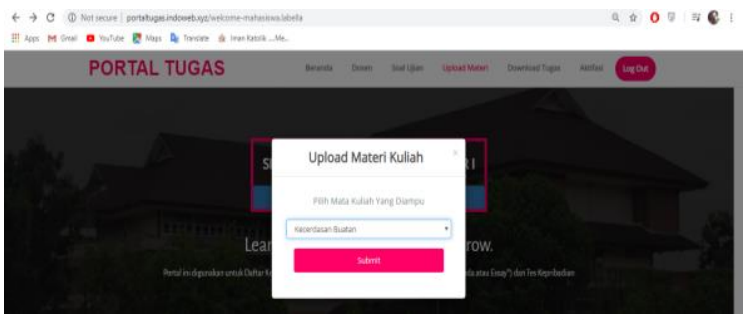

Gambar 13. Menu Upload Mata Kuliah k. Tampilan Halaman Upload Materi Kuliah

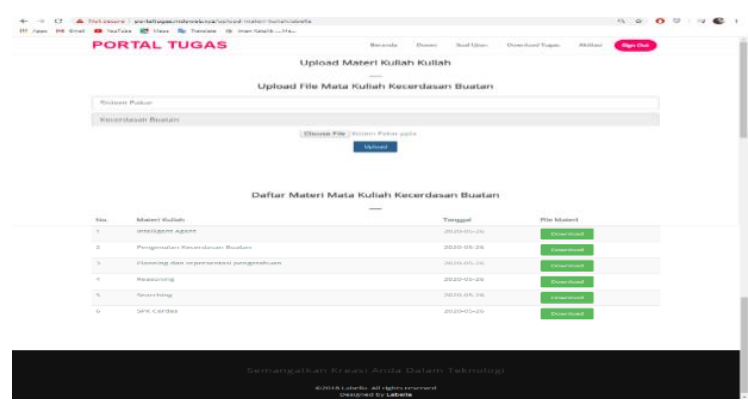

Gambar 14. Tampilan Halaman Upload Materi Kuliah

1. Tampilan Daftar Mata Kuliah yang Berhasil diupload

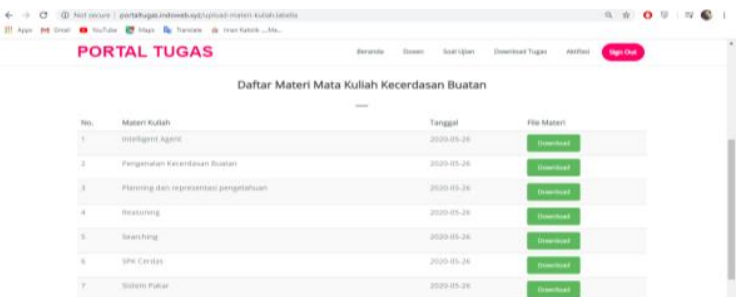

Gambar 15. Tampilan semua mata kuliah yang berhasil di-upload

m. Tampilan Awal E-Learning Edu IT (Mhs)

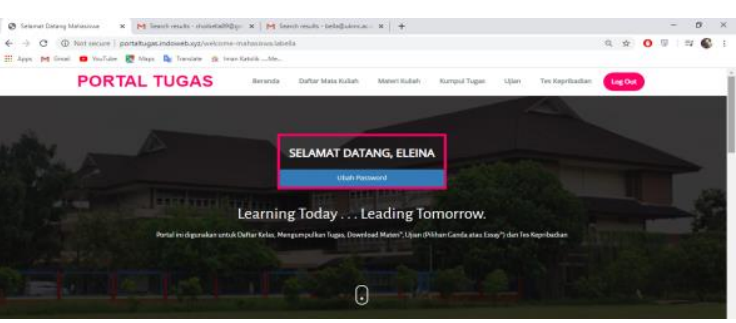

Gambar 16. Tampilan Awal E-Learning Edu IT

n. Tampilan Menu Ujian

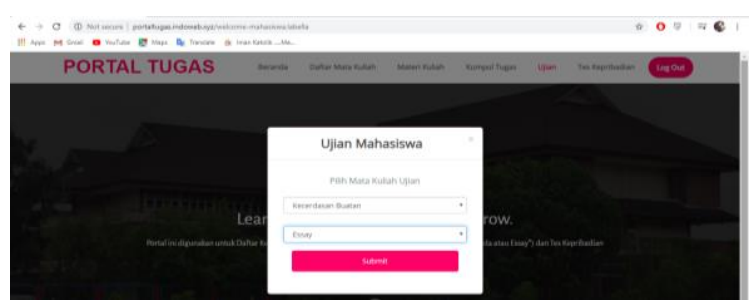

Gambar 17. Tampilan Mata Kuliah yang sudah dipilih untuk Ujian

\section{o. Tampilan Form Mulai Ujian}

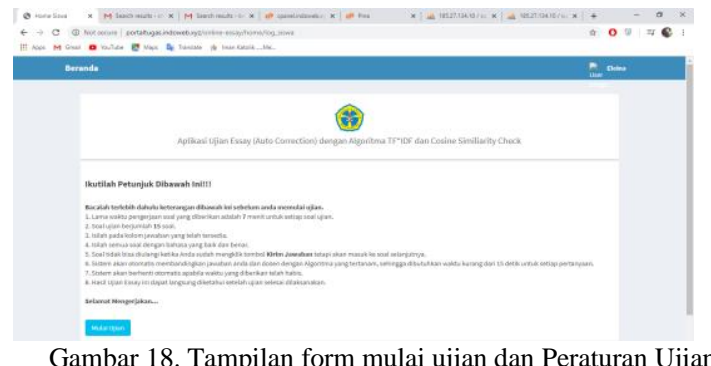




\section{p. Tampilan Form Ujian Essay Online}

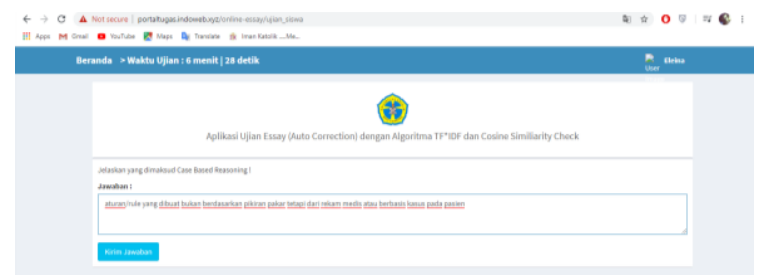

Gambar 19. Tampilan form Ujian Essay Online

\section{q. Tampilan Form Selesai Ujian}

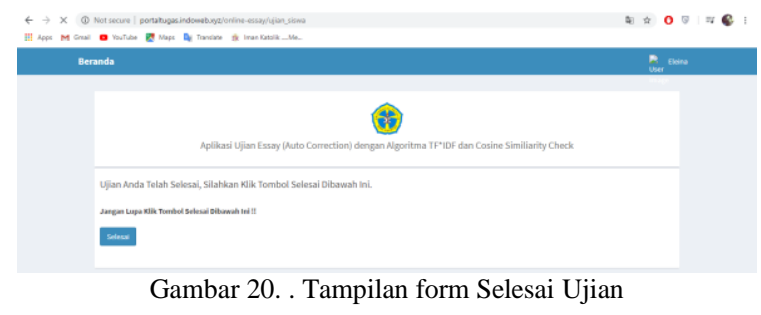

r. Tampilan Form Hasil Penilaian Ujian Mahasiswa

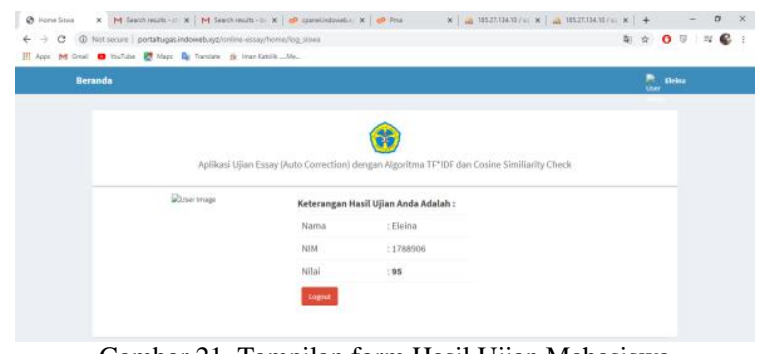

Gambar 21. Tampilan form Hasil Ujian Mahasiswa

s. Tampilan Form Download Materi Kuliah

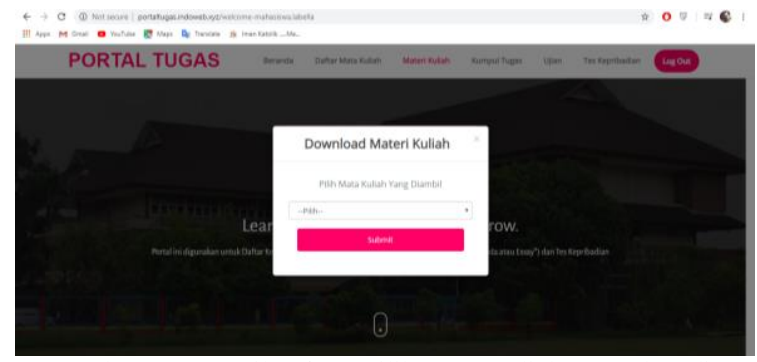

Gambar 22. Tampilan form Pilih Mata Kuliah yang akan didownload

t. Tampilan Halaman Download Materi Kuliah

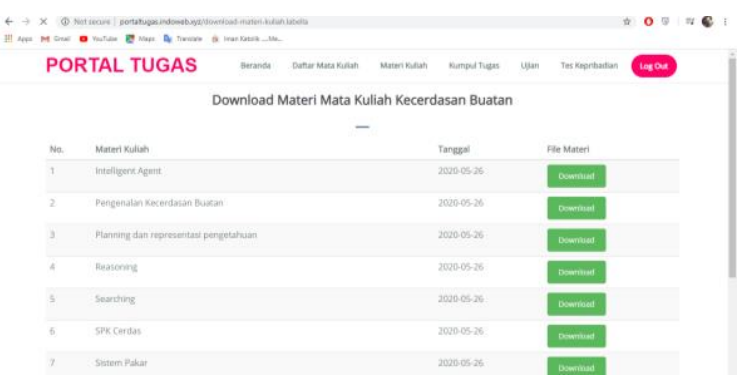

Gambar 23. Tampilan halaman untuk Download Materi Kuliah

\subsection{Hasil Pengujian Kuisioner Responden}

Kuisioner ini dilakukan dengan menggunakan Google Form dengan menggunakan responden yang sudah pernah mengikuti ujian essay online di website yang dibuat peneliti. Terdapat 30 responden yang telah menggunakan aplikasi tersebut dengan hasil sebagai berikut : $90 \%$ berpendapat bahwa aplikasi ini menjadi sesuatu yang baru bagi pembelajaran para mahasiswa, 93,3\% berpendapat bahwa aplikasi ini mudah dioperasikan, 93,3\% berpendapat bahwa nilai ujian sesuai dengan jawaban yang mahasiswa input-kan dalam aplikasi, dan sebanyak $100 \%$ berpendapat bahwa aplikasi ujian essay online lebih efisien daripada ujian secara konvensional.

Selain pengujian untuk aplikasi ujian essay online, dilakukan pula pengujian untuk menu upload dan download materi kuliah. Terdapat pula 30 responden yang telah menggunakan menu tersebut dengan hasil sebagai berikut : $100 \%$ berpendapat bahwa menu upload download dapat berjalan sesuai fungsinya, 96,7\% berpendapat bahwa menu ini mudah dioperasikan, dan $100 \%$ berpendapat bahwa dengan menggunakan menu ini maka manajemen pengaturan materi-materi kuliah menjadi lebih rapi.

\section{KESIMPULAN} adalah :

Simpulan yang didapatkan dari penelitian ini

1. Dari aplikasi ujian essay online yang telah dibuat, aplikasi ini dapat berfungsi sebagaimana mestinya yaitu dapat melakukan ujian essay online dengan lancar serta dapat menampilkan nilai ujian dari mahasiswa yang mengerjakan aplikasi ujian essay online tersebut. Nilai ujian berhasil didapatkan dengan mengecek nilai kemiripan/nilai cosine yang didapatkan oleh masing-masing mahasiswa. Aplikasi ujian essay online ini juga dibuat untuk melengkapi aplikasi portal tugas yang telah dibuat pada penelitian sebelumnya.

2. Fitur untuk upload dan download juga dapat berfungsi sebagaimana mestinya. Dosen tidak ada kendala saat melakukan upload materi dan mahasiswa juga tidak mempunyai kendala untuk melakukan download materi kuliah di web portal tugas tersebut.

3. Hasil pengujian kepada para mahasiswa yang sudah memakai kedua fitur tersebut mendapatkan hasil yang baik, artinya kedua fitur tersebut membantu para mahasiswa dan juga dosen dalam melakukan dan mengoreksi ujian online serta memanajemen file materi kuliah dengan rapi.

\section{DAFTAR PUSTAKA}

ARIEF, M.Rudianto. 2011. Pemrograman Web Dinamis Menggunakan Php dan Mysql. Yogyakarta: ANDI. 
ARIKUNTO, S. 2008. Prosedur Penelitian Suatu Pendekatan Praktik. Jakarta: Rineka Karya.

BETHA, Sidik. 2012. Pemrograman Web dengan PHP. Informatika. Bandung.

BLACK, Rex. 2009. Managing The Testing Process:Practical Tools and Techniques for Managing Hardware and Software Testing. Indiana: Wiley Publishing.Inc.

BRITTON, Carol. 2001. Object-Oriented Systems Development. McGraw-Hill. hlm. 28-29, 269. ISBN 0-07-709544-8.

FATTA, Al Hanif. 2007. Analisis \& Perancangan Sistem Informasi. Yogyakarta : Penerbit ANDI.

HARTLEY, Darin E. 2001. Selling E-Learning. American Society for Training and Development

HIGNASARI, L. Virginayoga dan Mardiki Supriadi. 2020. Pengembangan E-Learning dengan Metode Self-Assessment untuk Meningkatkan Hasil Belajar Matematika Mahasiswa Universitas Mahendradatta. Jurnal Kependidikan: Jurnal Hasil Penelitian dan Kajian Kepustakaan di Bidang Pendidikan, Pengajaran dan Pembelajaran, Volume 6, Nomor 2, Edisi Juli.

HOETAMY, Dinda Moulidyna, Agus Nugroho, dan Abdul Harris. 2020. Perancangan ELearning Pada SMK Veteran Kota Jambi Berbasis Android. Jurnal Ilmiah Mahasiswa Teknik Informatika, Volume 2, Nomor 2, Edisi Juni.

SAFAAT, Nazruddin H. 2012 (Edisi Revisi). Pemograman Aplikasi Mobile Smartphone dan Tablet PC Berbasis Android. Informatika. Bandung.

SAFAAT, Nazruddin H. 2012. " Pemrograman Aplikasi Mobile Smartphone dan Tablet PC berbasis android, Cetakan Pertama, Edisi Revisi. Informatika. Bandung.

SARI, Elsi Puspita, Sukardi, Elfi Tasrif, dan Ambiyar. 2020. Optimalisasi Penggunaan E-learning dengan Model Delone dan McClean. Journal of Education Technology, Volume 4, Nomor 2, Edisi Mei.

SUSANTI, Wilda, Rangga Rahmadian Yuliendi, Ambiyar, dan Wakhinuddin. 2020. Perancangan Pembelajaran E-Learning Bahasa Inggris Untuk Pemula Berbasis Multimedia. Jurnal Pendidikan, Volume 18, Nomor 1, Edisi Juni. 
Halaman ini sengaja dikosongkan 